\title{
Metasztázis miatt végzett máj- és hasfalreszekció 11 évvel a pancreatoduodenectomia után
}

\author{
Biró Zsanett dr. ${ }^{1}$ - Papp Róbert dr. ${ }^{1}$ - Kucserik Levente dr. ${ }^{2}$ \\ Al-Farhat Yousuf dr. ${ }^{3}$. Fincsúr András dr. ${ }^{4}$ \\ Vereczkei András dr. ${ }^{1}$. Kelemen Dezső dr. ${ }^{1}$ \\ ${ }^{1}$ Pécsi Tudományegyetem, Általános Orvostudományi Kar, Klinikai Központ, Sebészeti Klinika, Pécs \\ ${ }^{2}$ Marosvásárhelyi Sürgősségi Klinika, Sebészeti Osztály, Marosvásárhely, Románia \\ ${ }^{3}$ Tolna Megyei Balassa János Kórház, Onkológia, Szekszárd \\ ${ }^{4}$ Pécsi Tudományegyetem, Általános Orvostudományi Kar, Patológia Intézet, Pécs
}

\begin{abstract}
A pancreasrák prognózisa kedvezőtlen. A betegség kiújulása típusosan főleg a posztoperatív első két évben történik. A késői és szoliter metasztázis azonban ritka. Esetünkben egy férfi beteg kórtörténetét mutatjuk be, aki hasnyálmirigyrák miatt radikális mútéten esett át. A betegnél 11 évvel később egy szoliter májmetasztázist diagnosztizáltak, amelyet az épben reszekáltunk. Egy évvel a mútét után betegünk jó általános állapotban van. Esetünk demonstrálja, hogy pancreastumor miatt reszekcióban részesített betegeknél indokolt lehet ismételt mútét késői, izolált metasztázis esetén. Orv Hetil. 2017; 158(28): 1109-1111.
\end{abstract}

Kulcsszavak: pancreasrák, késői metasztázis, májreszekció

\section{Resection of liver and abdominal wall metastasis 11 years after pancreatoduodenectomy}

\section{Case report}

Pancreatic cancer has adverse prognosis. Disease recurrence is typical and it occurs mainly within the first 2 years postoperatively. However late and soliter metastases are rare. This case report shows the history of a male patient, who was radically operated on for pancreatic cancer. 11 years later a solitary liver metastasis has developed and it was completely removed by resection. 1 year postoperatively the patient is doing well. Our case demonstrates that in patients after resection for pancreatic cancer, redo surgery might be justified in case of late and isolated metastasis.

Keywords: pancreatic cancer, late metastasis, liver resection

Biró Zs, Papp R, Kucserik L, Al-Farhat Y, Fincsúr A, Vereczkei A, Kelemen D. [Resection of liver and abdominal wall metastasis 11 years after pancreatoduodenectomy. Case report]. Orv Hetil. 2017; 158(28): 1109-1111.

(Beérkezett: 2017. február 16.; elfogadva: 2017. március 6.)

A malignus betegségek között a pancreasrák agresszívabb lefolyású, az ötéves túlélés $10-20 \%$ a reszekciót követően. A hosszú távú túlélés eléréséhez azonban az egyetlen lehetőség a radikális mütét kiegészítve adjuváns onkológiai kezeléssel $[1,2]$. Szintén fontos tényező a túlélés szempontjából, hogy ezeket a beavatkozásokat erre specializálódott sebészeti centrumokban végezzék, ezzel az operatív mortalitást $5 \%$ alá sikerült csökkenteni [3]. Minden erőfeszítés ellenére a betegség 80\%-ban kiújul a műtétet követő első két évben [4]. A betegek többsége ezért a lokális és/vagy távoli metasztázisoktól szenved. Ezekben az esetekben a sebészeti beavatkozás szerepe kétséges. Bizonyos esetekben az izolált metasztázis reszekciója elvégezhető, azonban általában csak néhány beteg alkalmas ezekre a megterhelő beavatkozásokra [5]. Esetünkben egy késői metasztázist adó pancreas-térfoglalás hosszú távú túlélését mutatjuk be. 


\section{Esetbemutatás}

A 40 éves férfi betegnek felhasi fájdalom miatt kezdődött kivizsgálása. Az elvégzett ultrahangos, majd CT-vizsgálat pancreasfej-térfoglalást valószínúsített. A malignitás gyanúja miatt pylorusmegtartásos Whipple-mútétet végeztünk, amely során a direkt tumorterjedés miatt a colon transversum szegmentális reszekcióját is elvégeztük. A posztoperatív szak eseménytelenül telt. A szövettani vizsgálat igazolta a malignitást. A pancreasfej térfoglalása jól differenciált ductalis carcinoma, nagy ductalis típusú volt. Patológiai stádiumát tekintve T3, amely a peripancreaticus zsírszövetet infiltrálta. Jelentôs volt a mucin termelése, valamint perineuralis inváziót is mutatott. A proliferációs ráta szokatlanul alacsony volt, körülbelül 3\%. A nyirokcsomóstátusz $\mathrm{Nl}$, a reszekció $\mathrm{Rl}$ volt (l. ábra). Ezt követően adjuváns onkológiai kezelés történt. Fluorouracilalapú kemoradioterápia indult $\left(500 \mathrm{mg} / \mathrm{m}^{2}\right.$ 5-FU az első és az ötödik héten, 45/1,8 Gy radioterápiával). Ezt fluorouracil + gemcitabin kezeléssel egészítet-

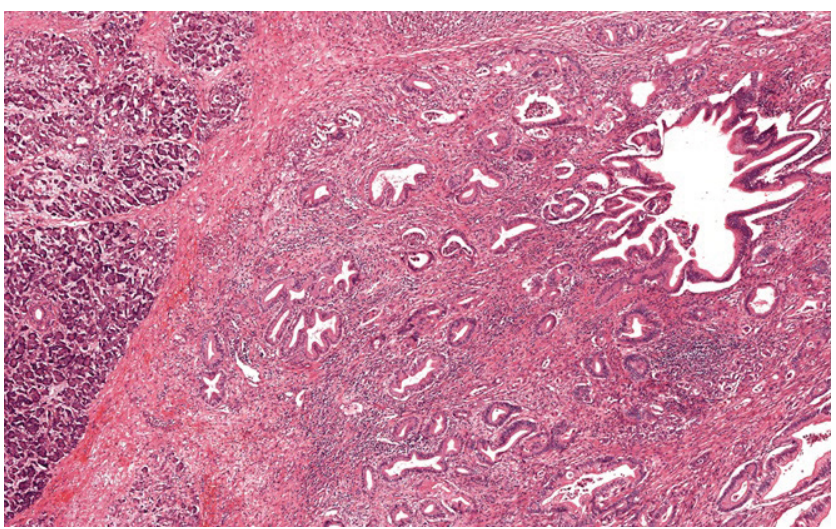

Pancreas ductalis carcinoma. A tumorszövet jól differenciált ductalis struktúrákat tartalmaz világos, meszes neostromalis háttérben a jobb oldalon. Bal oldalon normális parenchyma látható

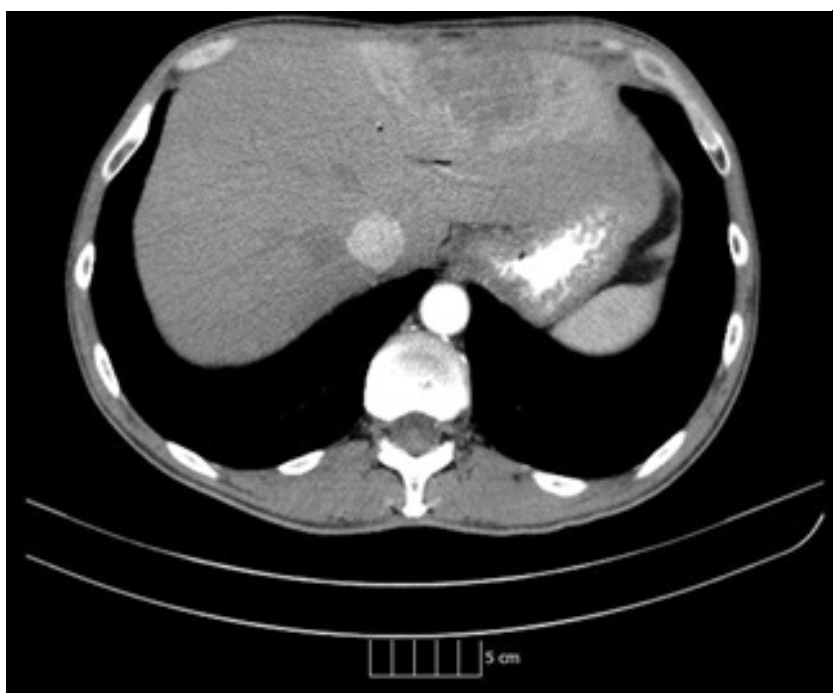

2. ábra

| A májmetasztázis CT-felvétele ték ki, a kemoradioterápia előtt három, azt követően két ciklussal. Az onkológiai ellenőrzések során, 11 évvel a radikális mútétet követően, epigastrialis fájdalmat és emelkedett CA19-9-szintet $(128 \mathrm{U} / \mathrm{ml})$ detektáltak. CT-vizsgálat történt, amely a máj II-III. szegmentumában írt le térfoglalást (2. ábra). Az elvégzett core-biopszia alapján az elváltozás a primer pancreasrák metasztázisának bizonyult. Az oncoteam kemoterápia mellett döntött. Mono-Gemcitabine protokoll alapján indult a kezelés (első vonalbeli Mono-Gemcitabine terápia $1000 \mathrm{mg} / \mathrm{m}^{2}$ ). Ennek ellenére a májmetasztázis progressziót mutatott, a hasfalban gyulladás alakult ki lázzal, emiatt sebészeti beavatkozás vált szükségessé. A hasfalban kialakult tályog miatt oncotomiát végeztünk, továbbá antibiotikum-terápia indult. Ezt követően rövidesen a gyulladás szanálódott, így el tudtuk végezni a máj II-III. segmentectomiáját a korábbi gyulladt hasfal eltávolításával együtt (3. ábra).

Posztoperatív szeptikus szövődmény nem volt. A mútéti preparátum teljes szövettani feldolgozása alátámasz-

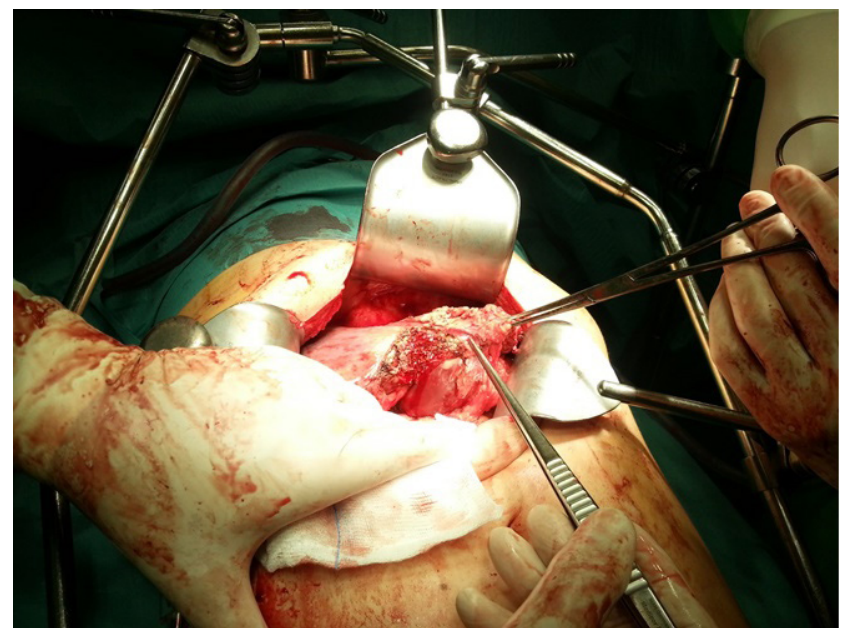

3. ábra $\quad$ A májmetasztázis intraoperatív felvétele

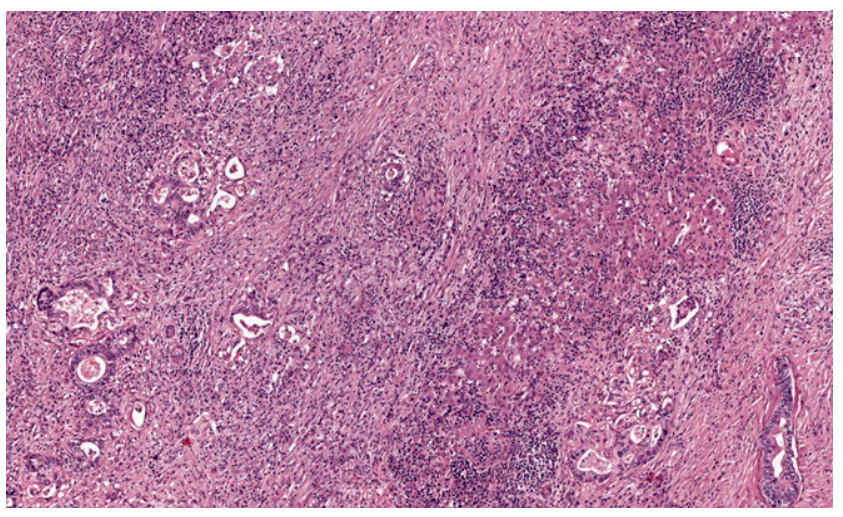

4. ábra $\mid$ Jól differenciált adenocarcinoma májinfiltrációja. Sok hasonlóság látható a pancreastumor hematoxilin-eozin szövettani képé vel, amelyet az immunhisztokémia megerősített 
totta a hasfali metasztázis pancreatobiliaris eredetét. A reszekció R0 volt. A szoliter májtumor szövettanilag szintén adenocarcinoma, számos mikromorfológiai és immunfenotípus-hasonlóságot mutatva a primer pancreas-térfoglalással. Mindkét preparátum CK7-pozitív és CK20-negatív volt. A pulmonalis és colorectalis eredetet a patológusok kizárták. A mucinszekréció mértéke azonos volt, ellenben ennek a tumornak a proliferációs rátája (Mib-1-reakcióval) magasabbnak bizonyult, körülbelül 20\%. Összességében a tumor pancreatobiliaris eredetűnek felel meg, a korábbi pancreasfejtumor metasztázisának (4. ábra). A mütétet követően az oncoteam a korábbi kemoterápia folytatása mellett döntött, de a beteg ezt elutasította. Egy évvel a metastasectomia után a beteg panasz- és tünetmentes.

\section{Megbeszélés}

A pancreasrák prognózisa kedvezőtlen. Egyedül a multimodális terápiától remélhetünk esélyt a gyógyulásra, nevezetesen radikális mütétet követő adjuváns onkológiai kezeléssel [1, 2]. Ezeket a beavatkozásokat követően is a pancreasrák ötéves túlélése csak 10-20\% közötti [6]. A tumor kiújulása a betegek döntő többségében megjelenik, és általában a palliatív onkológiai kezelés az egyetlen lehetőség ezekben az esetekben. Kivételes esetekben azonban a sebészeti beavatkozás sikeres lehet, amennyiben izolált, szoliter metasztázisról van szó és a beteg általános állapota megengedi a mütéti megterhelést. A döntés előtt bizonyos diagnosztikus lépések szükségesek, úgymint CT, PET-CT elvégzése, tumormarkerszintmeghatározás, a beteg általános állapotának felmérése. A primer mütéthez képest minél később jelenik meg a recidíva, annál jobb prognózist mutat. Amennyiben ez az idő több mint 15 hónap, akkor a túlélés szignifikánsan magasabb [7]. Szintén megfigyelhető tendencia a hoszszabb túlélés irányába lokális recidíva vagy tüdőmetasztázis esetén, összehasonlítva a májmetasztázisokkal [5]. Ismételt mütét esetén számos lehetőség létezik, úgymint máj- vagy tüdőreszekció, totális pancreatectomia, nyirokcsomó-dissectio, bypass, a pancreaságy reszekciója, rádiófrekvenciás ablatio vagy intraoperatív besugárzás $[5,7-9]$.

Esetünkben a fiatal férfi beteg 11 évvel a korábbi Whipple-mútétet követően szoliter májmetasztázis eltávolításán esett át. Az irodalomban eddig leírt leghoszszabb idő a primer mútét és a recidíva közt 49 hónap [7], ami jóval kevesebb az általunk ismertetett esetnél. Továbbá a mütéttel a tumort R0-ra sikerült reszekálnunk. Nyilvánvalóan az előnyök értékeléséhez hosszabb követési idő szükséges, de válogatott esetekben az ismételt mútét recidíva esetén indikált lehet.
Anyagi támogatás: A közlemény megírása anyagi támogatásban nem részesült.

Szerzői munkamegosztás: B. Zs.: A kézirat megszövegezése, eredmények feldolgozása és adaptálása. P. R.: A mütét elvégzése, az eredmények feldolgozása és adaptálása. K. L.: Az eredmények feldolgozása és adaptálása. A.-F. Y.: Onkológiai kezelés, az eredmények feldolgozása és adaptálása, a közlemény felülvizsgálata. F. A.: Szövettani feldolgozás, az eredmények feldolgozása és adaptálása, a közlemény felülvizsgálata. V. A.: A közlemény felülvizsgálata. K. D.: A mütét elvégzése, az eredmények feldolgozása és adaptálása, a közlemény felülvizsgálata. A cikk végleges változatát valamennyi szerző elolvasta és jóváhagyta.

Érdekeltségek: A szerzőknek nincsenek érdekeltségeik.

\section{Irodalom}

[1] Gaedcke J, Gunawan B, Grade M, et al. The mesopancreas is the primary site for Rl resection in pancreatic head cancer: Relevance for clinical trials. Langenbeck's Arch Surg. 2010; 395: $451-458$.

[2] Neoptolemos JP, Stocken DD, Friess H, et al., for the European Study Group for Pancreatic Cancer. A randomized trial of chemoradiotherapy and chemotherapy after resection of pancreatic cancer. N Engl J Med. 2004; 350: 1200-1210.

[3] Büchler MW, Wagner M, Schmied BM, et al.: Changes in morbidity after pancreatic resection: toward the end of completion pancreatectomy. Arch Surg. 2003; 138: 1310-1314.

[4] Smeenk HG, Tran TC, Erdmann J, et al. Survival after surgical management of pancreatic adenocarcinoma: does curative and radical surgery truly exist? Langenbeck's Arch Surg. 2005; 390: 94-103.

[5] Boone BA, Zeh HJ, Mock BK, et al. Resection of isolated local and metastatic recurrence in periampullary adenocarcinoma. HPB 2014; 16: 197-203.

[6] Cameron JL, Riall TS, Coleman J, et al. One thousand consecutive pancreaticoduodenectomies. Ann Surg. 2006; 244: 10-15.

[7] Kleeff J, Reiser C, Hinz U, et al. Surgery for recurrent pancreatic ductal adenocarcinoma. Ann Surg. 2007; 245: 566-572.

[8] Zacharias T, Oussoultzoglou E, Jaeck D, et al. Surgery for recurrence of periampullary malignancies. J Gastrointest Surg. 2009; 13: 760-767

[9] Hackert T, Büchler MW, Werner J. Current state of surgical management of pancreatic cancer. Cancers 2011; 3: 1253-1273.

(Biró Zsanett dr., Pécs, Ifjúság útja 13., 7624 e-mail: biro.zsanett.katalin@gmail.com) 